\title{
Color Evaluation in the Cane Sugar Industry ${ }^{1}$
}

\author{
Victor R. Deitz
}

\begin{abstract}
A fundamental unit of sugar color based on the National Bureau of Standards color scale is described and used to evaluate a variety of commercial sugar products. The results are in good agreement with actual visual experience. The proposed scale is based on color differences, whereby the color of the sugar solution is evaluated by the amount of departure from a colorless sucrose solution. Some information on spectral distribution is lost, but this is balanced by the great gain in simplicity. A special color chart is presented, whereby the value of the color can be read directly from a knowledge of the attenuation at wavelengths 420 and 560 millimicrons.
\end{abstract}

\section{Introduction}

In the sugar industry it is generally agreed that color is of prime importance. Since early in the 19 th century, the industry has used an estimation of color in four general ways. First, raw sugars were originally described by their color and taste, especially those once known as the Muscovado sugars [1]. ${ }^{2}$ Today, color is only an incidental factor in the purchase of raw sugars. Second, a comparative measure of color is used by all manufacturers and refiners as an index to the changes that occur during processing. These values serve for comparison and for record, and from them an operating staff can adjust the variables of the process to obtain an acceptable product. Third, color is used to evaluate liquid sugar products. This is a contemporary development and makes important demands on visual color measurement. It has emphasized the need for a universal color evaluation based on fundamental units.

The fourth important use of color measurement is for the evaluation of an adsorbent. The first

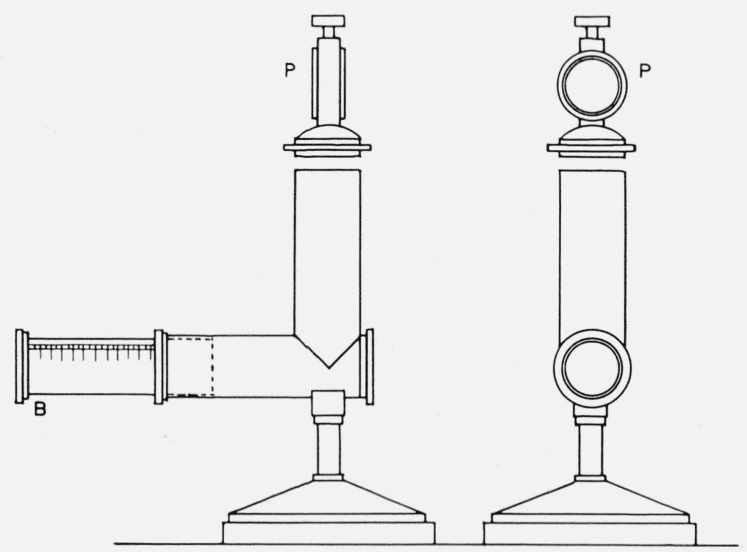

Figure 1. Payen's décolorimètre proposed in 1822 to evaluate the color removal capacity of bone char.

The decolorized solution is contained in the long tube (B) and matched against The decolorized solution is contain
a short depth of the initial liquor $(\mathrm{P})$.

1 This investigation was sponsored as a joint research undertaken by the Bone Char Research Project, Inc., and the National Bureau of Standards.

2 Figures in brackets indicate the literature references at the end of this paper. quantitative color measurement was apparently made in 1822 by M. Payen [2], who described a procedure to evaluate the capacity of finely divided bone char to remove color. In fact, the instrument he invented and described was called a "décolorimètre" and is shown in figure 1. The visual appearance of the decolorized solution contained in the long tube was matched against a smaller depth of the initial liquor. The cell depth was adjusted until a match was obtained. Color determinations for the evaluation of adsorbents have been used ever since, and many kinds of colorimeters have been devised.

The greatest obstacle to the successful use of color measurement in the sugar industry has been the lack of standards and of a suitable color unit. During the last 50 years many reference materials have been proposed, but none has been satisfactory in all respects. The object of this paper is to present the NBS unit of sugar color and to describe some typical applications of color measurements.

\section{General Characteristics of the Spectro- photometric Data}

Spectrophotometric measurements in the visual spectrum supply the primary data for the calculation of sugar color on the NBS scale. The comparatively recent introduction of various commercial spectrophotometers has made possible the examination of sugar liquors in sugar laboratories and has justified the proposed new approach to the measurement of an index of visual color. Typical graphs of the transmittancy of commercial sugar solutions as a function of wavelength are given in figure 2 . These data have two general characteristics: (1) the transmittancy always increases as the wavelength changes from the short-wave (blue) end of the visible spectrum to the long-wave (red) end, and (2) a simple algebraic relationship exists between the increase in transmittancy and wavelength.

It is seen in figure 3 that the logarithm of the attenuancy ${ }^{3}$ follows closely a linear variation with

3 The term "attenuancy" $\left(A^{*}\right)$ was introduced by Deitz, Pennington, and Hoffman [12] to replace absorbancy $(A)$ for those solutions that contain appreciable light-scattering material. The presence of appreciable light-scattering impurities invalidates Beer's law. $A^{*}$ is defined as $-\log _{10}\left[T_{\text {solution }} / T_{\text {solvent }}\right]$. 


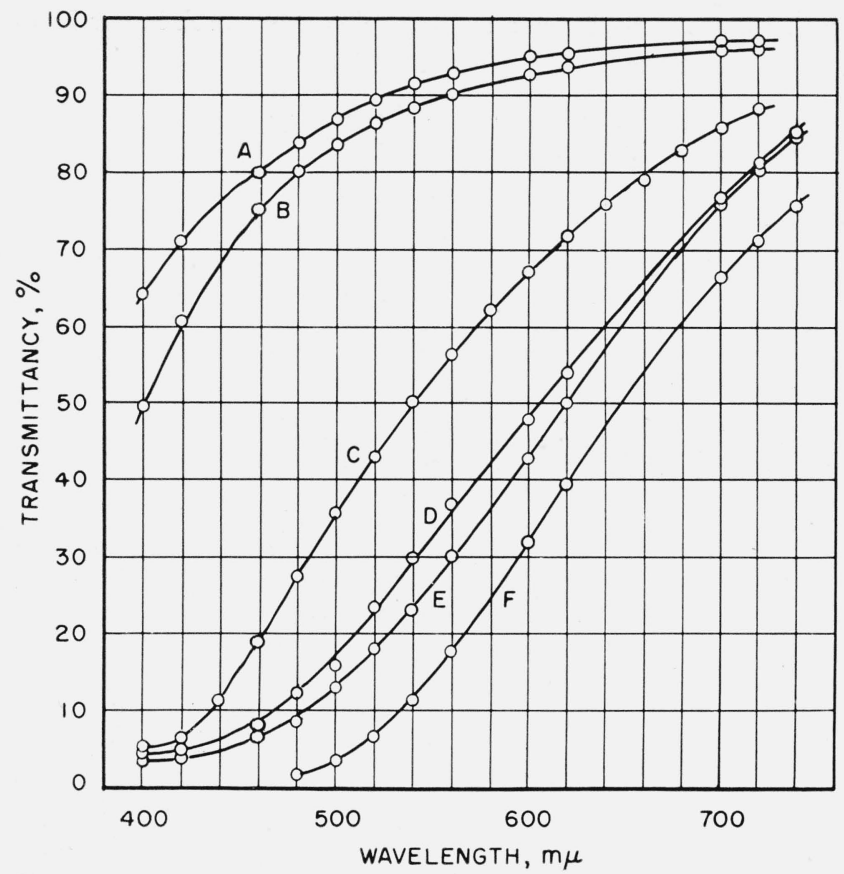

FIGURE 2. Transmittancy curves for typical sugar liquors at a solids concentration between $0.7 \%$ and 0.78 grams per milliliter.

A, granulated sugar $(b=10 \mathrm{~cm})$; B, char-treated whole Cuban raw $(b=1 \mathrm{~cm})$; C, washed Cuban raw $(b=1 \mathrm{~cm}) ; \mathrm{D}$, whole Hawaiian raw $(b=0.5 \mathrm{~cm}) ; \mathrm{E}$, whole Cuban raw $(b=0.5 \mathrm{~cm}) ; \mathrm{F}$, blackstrap $(b=0.041 \mathrm{~cm})$, where $b$ is cell depth.
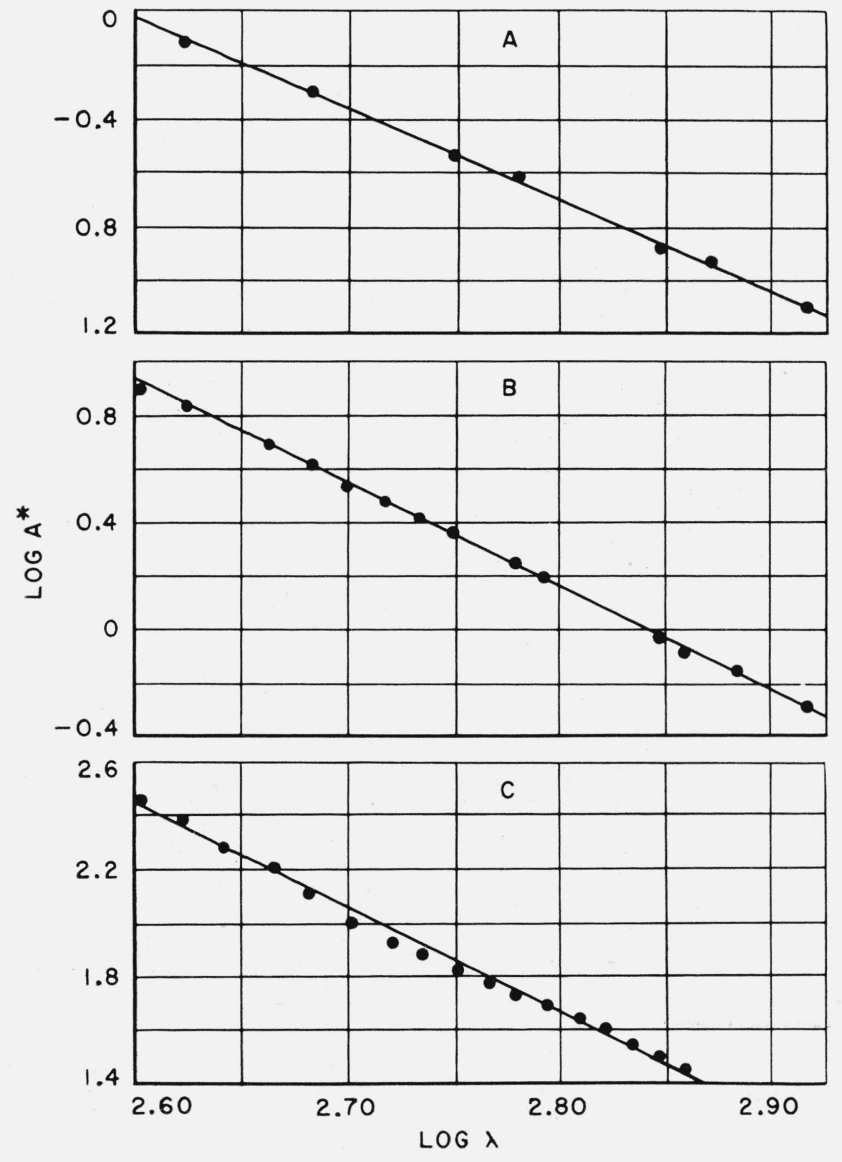

the logarithm of the wavelength $(\lambda)$. The behavior shown in figure 3 has been confirmed for many other sugar products. The linear relationship between $\log A^{*}$ and $\log \lambda$ makes possible a real simplification in the evaluation of visual sugar color on the NBS scale. Because two points are necessary to define a straight line, it is possible to construct the complete spectrophotometric curve from transmittancy observations at only two wavelengths.

\section{Scope of the Optical Measurement}

To obtain perspective in the determination of color of commercial sugar liquors, several factors that influence the optical measurement must be considered. The appearance of a sugar liquor is influenced by both the dissolved impurities and the colloidal suspended solids. It is important to recognize that there can be dissolved impurities with no color and, likewise, suspended matter with no turbidity. If the term "color" is reserved for a description of visual appearance, the sugar industry is on common ground with almost all other industries where color is an important factor. Zerban [3] has stressed that the sugar chemist needs information on the quantity and nature of the coloring matter present in sugar products. It is obvious that transmittancy has definite limitations for such a purpose as a nonsugar impurity without color and showing no turbidity may escape detection by a photometric measurement alone.

Experience has shown that two-word terms, such as "color bodies," "coloring material," etc., tend to be abbreviated to "color" and lose their distinctive meaning. The general term "colorant" has been used by physicists to indicate material that is either a dye that absorbs light with negligible scattering, or a pigment that both absorbs and scatters. It is recommended to the sugar industry as a term to designate the coloring materials in sugar. The sources of the colorant in sugar liquors are complex and are not known with any degree of certainty. Gillett [4] suggested a classification into three general categories: (1) colored nonsugars originally in the sugar cane, (2) colorless nonsugar bodies that may develop color, and (3) colored nonsugar bodies that result from decomposition of the sugar. The formation of the colorant bodies has been attributed to complex reactions between invert sugar, organic acids, certain inorganic salts, and nitrogenous compounds such as proteins. This viewpoint again indicates a limitation on the use of color (i. e., visual appearance) as a measure and identification of the colorant bodies present in commercial sugar products. The considerations that follow are solely concerned with the visual measurement, which is of value to the industrial sugar chemist.

Figure 3. Linear dependence of $\log A^{*}$ on $\log \lambda$ for three sugar products.

A, Granulated sugar $(b=10 \mathrm{~cm}, c=0.613 \mathrm{~g} / \mathrm{ml})$; B, Cuban raw, unfiltered $(b=0.2$ $\mathrm{cm}, c=0.780 \mathrm{~g} / \mathrm{ml}) ; \mathrm{C}$, Blackstrap $(b=0.2 \mathrm{~cm}, c=0.0204 \mathrm{~g} / \mathrm{ml})$, where $b$ is cell depth and $c$ is total solids concentration. 


\section{NBS Unit of Sugar Color}

It is well known that perception of color is tridimensional. Zerban and his associates $[5,6]$ have specified the colors of a variety of raw and refined sugars by use of the coordinate luminous transmit- tancy (also called brightness), and two other coordinates to describe the chromaticity, namely, the purity and the dominant wavelength. They found that the dominant wavelength varied only slightly (573 to $578 \mathrm{~m} \mu$ ), which indicated that only one variable was sufficient to define the chromaticity of

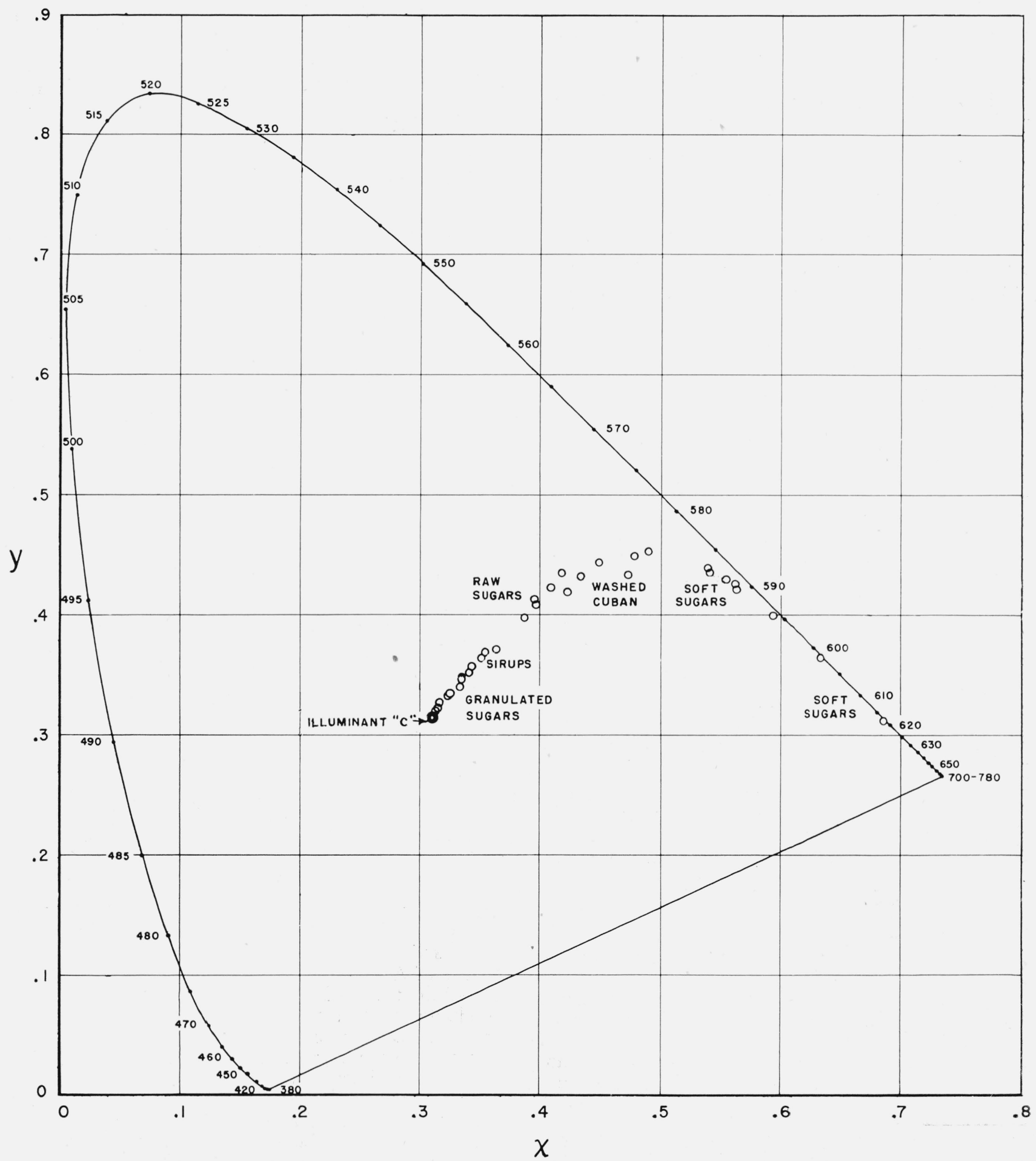

Figure 4. Chromaticity plot for various sugar liquors according to the 1931 ICI standard observer and coordinate system [7]. 
sugar colors. Liggett and Deitz [7] plotted, as in figure 4, the chromaticity coordinates for a variety of commercial sugar products and found that the majority of the points were grouped within a narrow band drawn from the point representing the standard light source $\mathrm{C}$ so as to approach asymptotically the spectrum red locus. The previously mentioned approximate linearity of the spectrophotometric data for commercial sugar solutions illustrated in figure 3 is another indication that sugar solutions have a simple colorimetric character.

There is another important way to view the problem. The differences between colors closely resembling each other can be evaluated with considerable precision and accuracy by the technique of small-difference colorimetry, and these differences can be expressed on a scale yielding high correlation with visual estimates of the differences [8]. Such a scale would permit the use of a single number to represent visual appearance, and could be readily applied to all phases of sugar manufacture and sale. It is true that in reducing the complete color specification to a single scalar quantity, some information is lost; however, because sugar colors occupy such a narrow band on the chromaticity diagram, the loss of this information is of minor consequence and may indeed be balanced by the great gain in simplicity.

The natural choice of a reference color in sugar colorimetry is that of a highly purified sucrose solution viewed with the standard light source C. ${ }^{4}$ It is proposed that all sugar colors be evaluated by the amount of departure from this colorless solution.

Of the several formulas already devised for evaluating color differences, the Adams formula [9] has been chosen as the basis for the proposed NBS scale because it meets the major requirement of expressing color by a scalar quantity on a uniform scale of perceptibility. The Adams formula is an empirical relation, which was developed for evaluating the difference between the nearly equal colors of two reflecting surfaces. The application of this formula to transmittancy data was reported in 1952 in the Technical Reports of the Bone Char Research Group. It is to be noted that the differences observed in many cases are not small and, hence, the formula for color difference is being used for a purpose other than that for which it was devised. Experiences to date indicate that this is not a substantive limitation.

\subsection{Complete Procedure}

The spectrophotometric data between 400 and $720 \mathrm{~m} \mu$ are converted first to the tristimulus values $X, Y, Z$. Computation forms for this calculation are given by Judd [8]. The Munsell value functions $V_{x}, V_{y}, V_{z}$, which are related to the tristimulus values, are then obtained from the table which was calculated by Nickerson [10] and quoted by Judd. ${ }^{5}$ The Munsell value functions are then substituted into the Adams equation.

4 The standard sources recommended in 1931 by the International Commission on Illumination are: Source A, representative of gas-filled incandescent lamps; source $B$, representative of noon sunlight; and source $C$, representative of average daylight, such as that from a completely overeast sky.

${ }_{5}$ See tables A, B, and C on pages 352,354 , and 356 , respectively, of [9].
Because one of the colors in the calculated difference will be the standard source $C$, the Munsell value functions for the reference sucrose solution $\left(X_{c}=\right.$ $Y_{c}=Z_{c}$ ) can be entered into the Adams equation, which can be written in the form

$$
\begin{aligned}
& \Delta E_{\mathrm{NBS}}= \\
& 50 \sqrt{\left[0.23\left(10-V_{y}\right)\right]^{2}+\left[V_{x}-V_{y}\right]^{2}+\left[0.4\left(V_{z}-V_{y}\right)\right]^{2}} .
\end{aligned}
$$

Under the conditions of observation used in the present work, which are given in detail in the subsequent paragraphs presenting the data, the observers could usually distinguish a difference of about one unit of $\Delta E_{\mathrm{NBS}}$. Therefore, the computations need be made only to the nearest integer.

Values of $\Delta E_{\mathrm{NBS}}$ for a variety of typical sugar products are given in table 1 at the conditions noted for cell depth and sugar solids. The values are, of course, dependent upon cell depth and the concentration of total sugar solids. Thus, a solution of a granulated sugar viewed in a very long cell can have a greater value of $\Delta E_{\mathrm{NBS}}$ than a diluted blackstrap viewed in a very short cell. This illustration serves

TABLE 1. Values of $\Delta E_{\mathrm{NBS}}$ for typical sugar products calculated for the specified depth and concentration

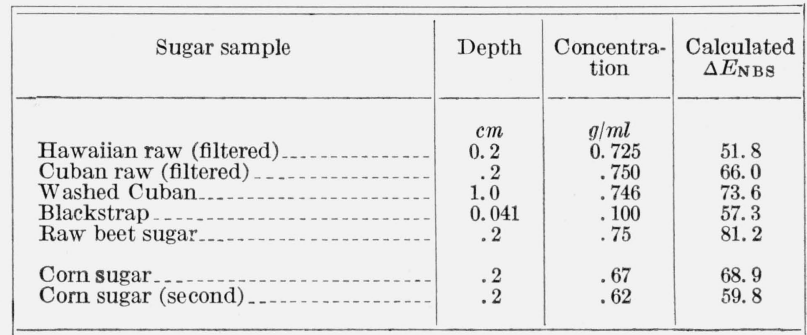

\begin{tabular}{|c|c|c|c|}
\hline Soft sugars $7 \mathrm{x}$ & 1.0 & 1. 0 & 74.2 \\
\hline Soft sugars $9 x_{\ldots} \ldots \ldots$ & 1.0 & 1.0 & 92.0 \\
\hline Soft sugars $10 \mathrm{x}_{\ldots}$ & 1.0 & 1.0 & 98.0 \\
\hline Soft sugars $11 \mathrm{x}$ & 1.0 & 1.0 & 108 \\
\hline Soft sugars $11 z_{\ldots}$ & 1.0 & 1. 0 & 108 \\
\hline Sirup 3a to pan.... & 1.0 & 1. 0 & 4.5 \\
\hline Sirup $3 \mathrm{c}$ from pan & 1.0 & 1.0 & 33.4 \\
\hline Granulated sugar (4a) .. & 1.0 & 1. 0 & 3.2 \\
\hline Granulated sugar (5d) ... & 1.0 & 1.0 & 5.8 \\
\hline Soft sugar $8 x$ & 1.0 & 1. 0 & 83.4 \\
\hline Soft sugar $2 z_{--}$ & 1.0 & 1.0 & 5.7 \\
\hline Soft sugar $3 z_{\ldots} \ldots$ & 1.0 & 1.0 & 11.9 \\
\hline Soft sugar $4 z_{\ldots} \ldots \ldots$ & 1.0 & 1. 0 & 19. 6 \\
\hline
\end{tabular}

Some products investigated by Peters and Phelps ${ }^{\circ}$

a H. H. Peters and F. P. Phelps. BS J. Research 2, 335 (1928) RP38.

only to emphasize that two sugar products must always be compared at the same concentration of sugar solids and cell depth. It has been found that values of $\Delta E_{\mathrm{NBS}}$ less than 40 are linear with respect to cell depth. It is not feasible to compare all sugar products at the same cell depth and sugar concentration. Efforts are being made by the National Committee for Sugar Analysis to specify these conditions for different types of products, and agreement on this point will be a real contribution to uniform reporting of results.

An additional specification must be made when the presence of suspensoids in sugar liquors is appreciable. The proposed evaluation of color tolerates the pres- 
ence of turbidity to such an extent that a small but definite Tyndall beam can be seen. However, for a reliable color evaluation it appears necessary to place an upper limit on the amount of the suspended matter present. It has been found that the color evaluation can be made with a reproducibility of about \pm 1 percent after the sugar liquor has been filtered through a fritted filter of Pyrex glass of porosity $F$. Experience usually dictates when such a filtration is necessary. Most refinery liquors require no filtration, particularly those for darkcolored products.

\subsection{Color Chart}

Because of the inherent simplicity of sugar colors, it has been found possible to obtain the color of a sugar liquor on the NBS color scale from a simple graph without using the Munsell value functions in the Adams formula. As the entire 'spectrophotometric curve can be defined by only two points, because of the linearity observed in figure 3 , the tristimulus values can be calculated from the curve defined by two observed points. Consequently, the value of $\Delta E_{\mathrm{NBS}}$ can also be determined from these same two points.

Two experimental points are used to represent the straight line in the plot of $\log A^{*}$ versus $\log \lambda$, namely, the values of $A^{*}$ at $420 \mathrm{~m} \mu$ and $560 \mathrm{~m} \mu$. The use of a wavelength near the shortwave extreme of the visible spectrum is particularly helpful because the absorption of sugar liquors is greatest in this part. The particular value at $420 \mathrm{~m} \mu$ was taken to agree with one of the wavelengths used by Gillett and Heath [11]. The wavelength of $560 \mathrm{~m} \mu$ corresponds to that extensively used in the pioneer work of Peters and Phelps [13].

The color chart calculated by the above procedure is shown in figure $5 .^{6}$ Specified values of $A_{420}^{*}$

6 The theoretical development of the color chart will be the subject of another publication by the Bone Char Research Project, Ine.

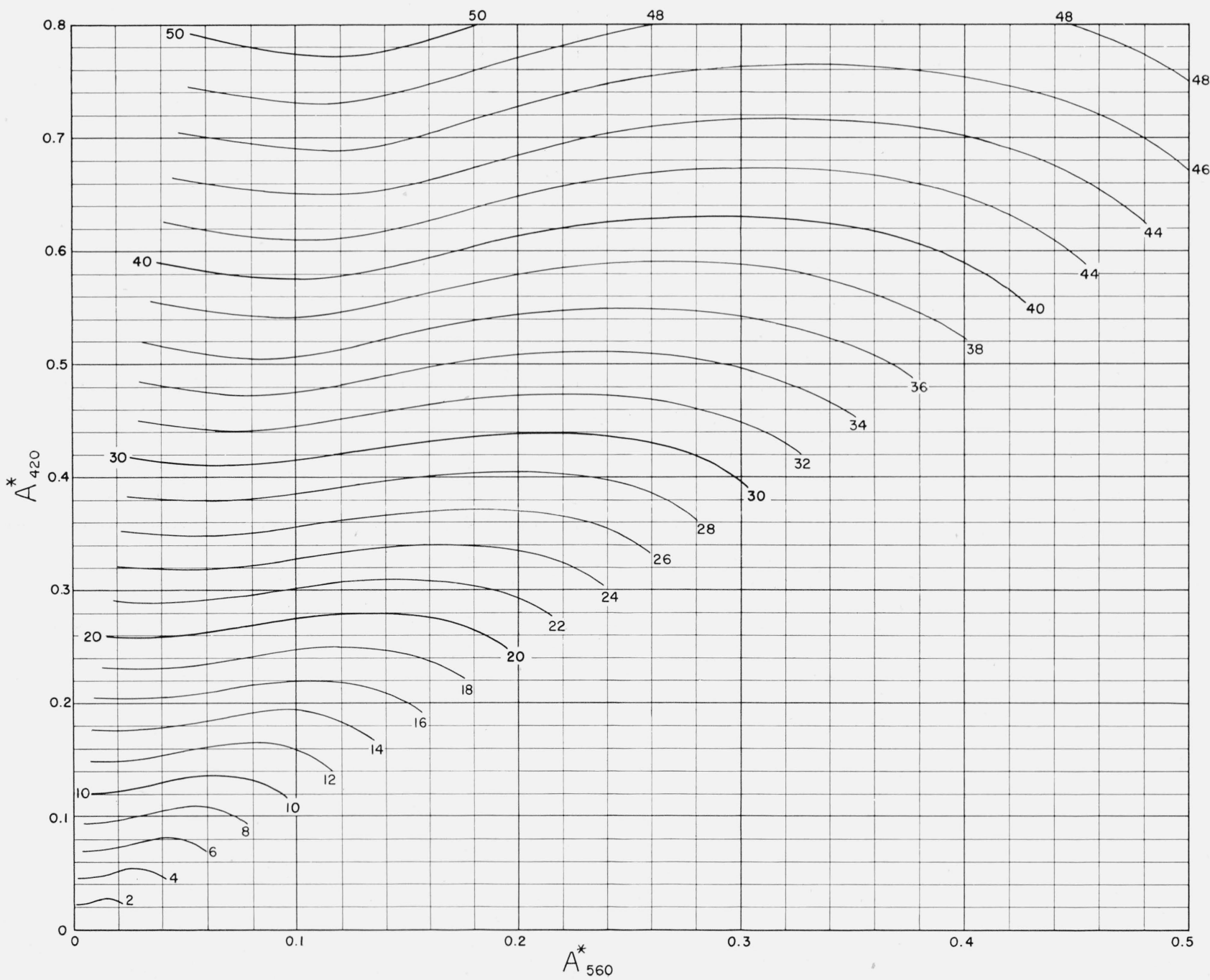

FIGURE 5. Color chart for the determination of sugar color in NBS units from attenuation values at 420 and 560 millimicrons. Numbers opposite curves are for specified values of $\Delta E_{\mathrm{NB}} S$. 
(ordinate) and $A_{560}^{*}$ (abscissa) determine a point on the graph and the position of this point is noted relative to the nearest curved lines. Each curved line represents a constant value of $\Delta E_{\mathrm{NBS}}$. Values of $\Delta E_{\mathrm{NBS}}$ that fall between the plotted lines may be estimated by interpolation.

The color chart has been checked in several ways. The values of $\Delta E_{\mathrm{NBS}}$ were calculated from the transmittancies over the visible spectrum for a great many sugar liquors and the results compared with the values determined from the color chart. Table 2 gives some of the results. The agreement, in general, is rather good, especially as the smallest difference detectable by the average eye is only about one unit. The coefficient of rank correlation ${ }^{7}$ is 0.99 . The colors of the sugar liquors described in tables 1 and 2 ranged from that of granulated sugars to that of blackstrap. The concentration of total solids and the cell depths must be adjusted to equality before comparisons among various products can be made.

Zerban and his associates, following the work of Peters and Phelps, proposed that the visual appearance of solutions of refined [5] and raw [6] sugars be quantitatively measured by the single value of the attenuancy index $(-\log t)$ at $560 \mathrm{~m} \mu$, where $t$ is the transmittancy at unit depth and solids concentration. As the spectrophotometric data at 420 $\mathrm{m} \mu$ and at $560 \mathrm{~m} \mu$ were given in these publications, it was possible to determine $\Delta E_{\mathrm{NBS}}$ from the color chart. Their data for dark sugars were compared at a cell depth of $0.1 \mathrm{~cm}$ and a solids concentration of $1 \mathrm{~g} / \mathrm{ml}$, and the white sugars were compared at a cell depth of $10 \mathrm{~cm}$ and at the same solids concentration. Table 3 shows that the arrangement in decreasing attenuancy at $560 \mathrm{~m} \mu$ for Zerban's data correlates in general with decreasing value of $\Delta E_{\mathrm{NBS}}$, but the agreement is far from perfect in regard to the sequence of decreasing values. There are a number of reversals; for example, Zerban's granulated sugars 48 and 59 have attenuancy values of 0.0680 and 0.0851 , respectively, but the corresponding values of $\Delta E_{\mathrm{NBS}}, 35$ and 29 , are in the reverse order. It is to be expected that attenuancy at 560 $\mathrm{m} \mu$ will correlate somewhat with visual appearance of sugar solutions because it is a direct measure of the darkness of the sugar color and, as attenuancy at $420 \mathrm{~m} \mu$ is somewhat correlated with attenuancy at $560 \mathrm{~m} \mu$, it is also an indirect measure of the yellowness of the sugar color. As $\Delta E_{\mathrm{NBS}}$ is based on direct measures of both yellowness and darkness, it is expected to yield a more reliable measure of visual appearance of sugar solutions, and these reversals may be interpreted chiefly as indications of the approximate nature of the connection between sugar color and attenuancy at the single wavelength $560 \mathrm{~m} \mu$.

7 The numerical calculations were made with the use of the following formula for the rank coefficient:

$$
r=1-\frac{6 S\left(d^{2}\right)}{n\left(n^{2}-1\right)},
$$

where $n$ is the number of observations and $S\left(d^{2}\right)$ is the sum of the squares of the rank-differences. The author is indebted to D. B. Judd of the Bureau for the suggestion that this statistical treatment be used.
TABLE 2. Comparison of $\Delta E_{\mathrm{NBS}}$ values obtained from the color chart with those calculated with the Adams equation

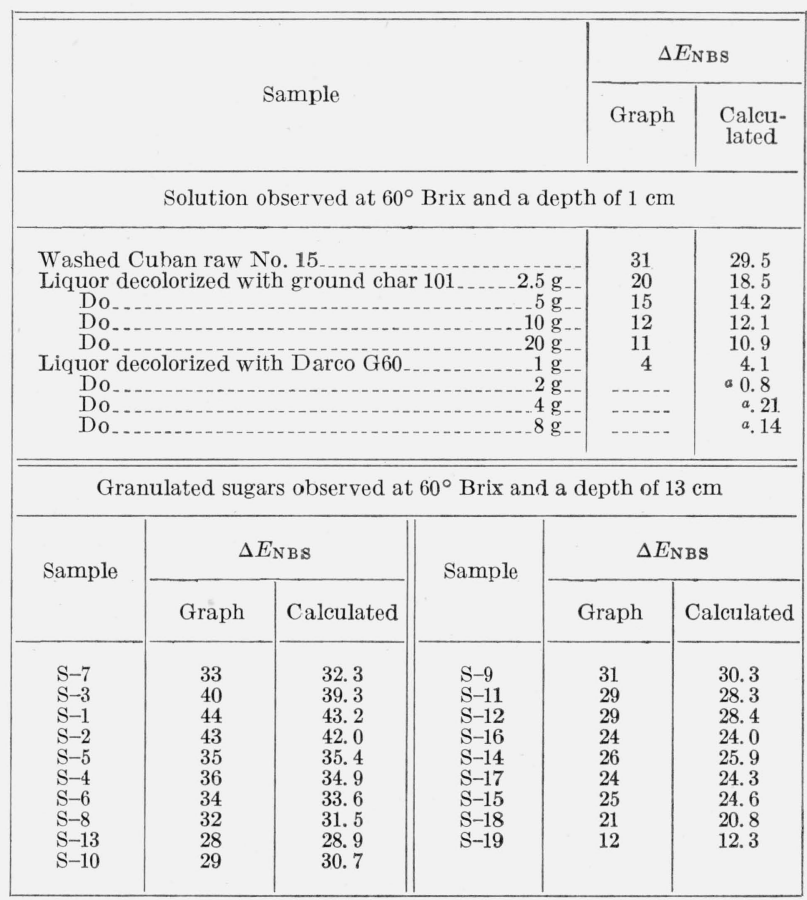

a The transmittancy was observed in a 10-cm cell and the attenuancy calculated to a $1-\mathrm{cm}$ cell.

TABLE 3. Calculation of $\Delta E_{\mathrm{NBS}}$ values from data reported by Zerban and his associates $[5,6]$

\begin{tabular}{|c|c|c|c|c|c|}
\hline \multicolumn{3}{|c|}{ Filtered raw sugars } & \multicolumn{3}{|c|}{ Granulated sugars } \\
\hline \multirow{2}{*}{ Sugar } & $b=0.1 \mathrm{~cm}$ & $c=1 \mathrm{~g} / \mathrm{ml}$ & \multirow{2}{*}{ Sugar } & $b=10 \mathrm{~cm}$ & $c=1 \mathrm{~g} / \mathrm{ml}$ \\
\hline & $A_{560}^{*} \mathrm{~m} \mu$ & $\Delta E_{\mathrm{NBS}}$ & & $A_{560}^{*} \mathrm{~m} \mu$ & $\Delta E_{\mathrm{NBS}}$ \\
\hline 18 & 0.0232 & 7 & 45 & 0.0022 & 4 \\
\hline 21 & $\begin{array}{l}.02329 \\
.032\end{array}$ & 12 & $\begin{array}{l}40 \\
39\end{array}$ & $\begin{array}{l}0.0042 \\
.0044\end{array}$ & 6 \\
\hline 42 & .0443 & 15 & 28 & .0097 & 9 \\
\hline $\begin{array}{l}42 \\
73\end{array}$ & .0477 & $\begin{array}{l}10 \\
19\end{array}$ & 17 & .0123 & 7 \\
\hline 51 & .0531 & 22 & 71 & .0132 & 10 \\
\hline 40 & .0550 & 19 & 56 & .0191 & 2 \\
\hline $\begin{array}{l}40 \\
86\end{array}$ & $\begin{array}{l}.0500 \\
.0625\end{array}$ & $\begin{array}{l}19 \\
23\end{array}$ & $\begin{array}{r}00 \\
6\end{array}$ & .0209 & 10 \\
\hline $\begin{array}{l}80 \\
29\end{array}$ & .0646 & 23 & 21 & .0255 & 17 \\
\hline $\begin{array}{l}29 \\
61\end{array}$ & $\begin{array}{l}.0040 \\
.0675\end{array}$ & 26 & $\begin{array}{l}21 \\
67\end{array}$ & .0301 & 15 \\
\hline 32 & .0705 & 21 & 11 & .0311 & 15 \\
\hline 74 & .0726 & 25 & 50 & .0329 & 19 \\
\hline $\begin{array}{l}r 4 \\
101\end{array}$ & .0748 & 30 & $\begin{array}{r}50 \\
7\end{array}$ & $\begin{array}{r}.0529 \\
.0376\end{array}$ & 17 \\
\hline $\begin{array}{r}101 \\
46\end{array}$ & .0780 & $\begin{array}{l}30 \\
25\end{array}$ & 38 & .0405 & $\begin{array}{l}18 \\
23\end{array}$ \\
\hline $\begin{array}{l}70 \\
36\end{array}$ & .0809 & 25 & 19 & .0482 & 21 \\
\hline 71 & .0867 & 33 & 25 & .0521 & 22 \\
\hline & .0905 & 31 & 84 & & 29 \\
\hline $\begin{array}{l}81 \\
20\end{array}$ & $\begin{array}{r}.0905 \\
.0946\end{array}$ & $\begin{array}{l}31 \\
31\end{array}$ & $\begin{array}{l}84 \\
48\end{array}$ & .0680 & 35 \\
\hline 9 & .1013 & $\begin{array}{l}31 \\
30\end{array}$ & 59 & .0851 & 29 \\
\hline $\begin{array}{r}9 \\
102\end{array}$ & $\begin{array}{l}.1010 \\
.1092\end{array}$ & 38 & 20 & .0851 & 38 \\
\hline 3 & .1192 & $\begin{array}{l}{ }^{8} \\
35\end{array}$ & 9 & .1415 & $\begin{array}{l}50 \\
59\end{array}$ \\
\hline 80 & .1352 & 43 & 85 & .4342 & 68 \\
\hline
\end{tabular}

When the values of $A_{560}^{*}$ in table 3 are plotted as a function of the corresponding $\Delta E_{\mathrm{NBS}}$, the plotted points approximate a straight line rather poorly. Although the calculated correlation coefficients for the ranking of these solutions were high (0.94 and 0.96 for the filtered raw and the granulated sugars, respectively), there are appreciable fluctuations based on the magnitudes of $A_{560}^{*}$ and $\Delta E_{\mathrm{NBS}}$. The 
TABLE 4. Results of arranging nine sugar liquors in order of decreasing color

\begin{tabular}{|c|c|c|}
\hline $\begin{array}{c}\text { Position of } \\
\text { samples visu- } \\
\text { ally deter- } \\
\text { mined }\end{array}$ & $\Delta E_{\mathrm{NBS}}$ & $\begin{array}{c}\text { Number of ob- } \\
\text { servers placing } \\
\text { sample in } \\
\text { position }\end{array}$ \\
\cline { 1 - 1 } & & \\
1 & 72 & 14 \\
2 & 52 & 14 \\
3 & 44 & 14 \\
4 & 38 & 14 \\
5 & 35 & 14 \\
6 & 13 & 14 \\
7 & 2.8 & 14 \\
8 & 1.0 & $a 13$ \\
9 & 0.4 & $a 13$ \\
\hline
\end{tabular}

ane observer reversed order of these samples.

small difference in the coefficients of rank is not meaningful for the data on hand.

A necessary requirement for the successful use of the proposed color unit in practice is a high correlation of values for $\Delta E_{\mathrm{NBS}}$ with the experience of various observers who may not necessarily be skilled in making scientific comparisons. Several experiments will now be described in which a number of observers were asked to arrange the sugar liquors in a sequence of decreasing color.

First, a series of nine filtered sugar liquors were prepared and tubes containing equal depths were alined by independent observers in a sequence of decreasing color. The liquors ranged from almost colorless to the color of a filtered washed Cuban raw sugar. The concentration of sugar solids was $60^{\circ}$ Brix. The solutions were contained in clear glass bottles of square cross section $(3.5 \mathrm{~cm}$ on side) and were compared in daylight with the bottles in contact side by side. Values of $\Delta E_{\mathrm{NBS}}$ were obtained independently from spectrophotometric data, using the color chart. The results, summarized in table 4, show that the alinement of the liquors according to both procedures is practically identical.

Second, another series of solutions was prepared in which the range of colors was not as great in order to bring out the differences in judgments among the observers. Solutions of 19 white sugars were prepared at a concentration of $60^{\circ}$ Brix. These solutions were not filtered and some turbidity was present. Each sample was contained in a test tube and viewed from above through a solution depth of $13 \mathrm{~cm}$. Daylight reflected from white paper was used as the light source and the surrounding field. Eight observers working independently were fairly successful in alining the solutions in a sequence of decreasing difference in color from that of distilled water. These data are given in table 5, a. The observers designated by A, B, C, D, E, I, J, and K were scientifically trained personnel and those designated by $\mathrm{F}, \mathrm{G}$, and $\mathrm{H}$ were not. Nevertheless, the agreement among all observers was good as measured by the calculated coefficient of concordance, ${ }^{8}$ which was 0.94 .

8 The coefficient of concordance, $W$, was calculated from the following expres sion, given by M. G. Kendall (Rank correlation methods, p. 81):

$$
W=\frac{12 S}{m^{2}\left(n^{3}-n\right)}
$$

where $m$ observers have made rankings of $n$ objects, and $S$ is the sum of squares of deviations of rank sums from the average $m(n+1) / 2$. The author is indebted to Joan R. Rosenblatt of the Bureau for the suggested use of this statistic.
Values of $\Delta E_{\mathrm{NBS}}$ were subsequently calculated from eq (1) and also obtained by using the color chart, and these are given in table 5 , a, with values for the attenuancy at $560 \mathrm{~m} \mu$ and for the combination $A_{420}^{*}-2 A_{720}^{*}$. Table 5, c, upper half, gives for each observer the rank correlations between the observer's ranking of the 19 unfiltered solutions and each of the rankings according to $\Delta E_{\mathrm{NBS}}, A_{560}^{*}$ and $A_{420}^{*}-$ $2 A_{720}^{*}$. It is seen that, with only one exception, each observer agrees with the $\Delta E_{\mathrm{NBS}}$ ranking better than with either of the others. Thus, the correlation of observed rankings with a ranking according to values of $\Delta E_{\mathrm{NBS}}$ is seen to be significantly (at the 0.10 -probability level) better ${ }^{9}$ than the correlation of observed rankings with rankings according to either $A_{560}^{*}$ or $\mathrm{A}_{420}^{*}-2 A_{720}^{*}$.

It was believed that the above differences might be attributed to the relatively high turbidity for the given amount of color present. Filtered solutions contain fewer light-scattering particles, and the ratio of the light absorbed to the light scattered is greater than in nonfiltered solutions. This situation frequently exists in commercial sugar products of very low color.

The experiment, therefore, was repeated for 10 of the 19 sugars after the solutions were filtered through a Pyrex sintered-glass filter (porosity $F$ ). These results are given in table $5, \mathrm{~b}$, and it can be seen that the agreement among all observers as to the alinement is very good. The calculated coefficient of concordance among the observers was 0.99 , as compared to 0.94 for the case of the unfiltered solutions. Reversals occur only where the magnitudes of $\Delta E_{\mathrm{NBS}}$ differ by only two units or less. Because values of $\Delta E_{\mathrm{NBS}}, \quad \dot{A}_{560}^{*}$, and $A_{420}^{*}-2 A_{720}^{*}$ were obtained for all of the solutions, the coefficients of rank correlation were calculated from the ranking of each of these quantities with the rankings established by the observers. The results are given in table 5, c, and it is seen that the filtered solutions show a consistently high correlation coefficient regardless of whether the index of color is taken as $\Delta E_{\mathrm{NBS}}, A_{560}^{*}$, or $A_{420}^{*}-2 A_{720}^{*}$. There are no meaningful differences between the various measurements on the filtered solutions with respect to the agreement of the observers.

The presence of a residual turbidity in commercial sugar liquors of low color is thus seen to have a marked influence. Many of the 19 sugars used in the above measurements were obtained from retail food stores. It was considered desirable to repeat the experiment with unfiltered granulated sugars selected for their minimum turbidity.

A series of 9 such granulated sugars were prepared at $50^{\circ}$ Brix, and these were arranged by 10 independent observers in a sequence of decreasing color under 2 experimental conditions. All solutions were contained in test tubes (17 cm long and $2 \mathrm{~cm}$ in diameter)

${ }^{9}$ A statistical procedure for determining the significance of the difference between the rank correlations is the "sign test"; see, for example, W. J. Dixon and F. J. Massey, Jr., Introduction to statistical analysis, p. $247 \mathrm{ff}$. and table 10 , p. 324 (McGraw-Hill, 1951). The author is indebted to Joan R. Rosenblatt of p. $324(\mathrm{McGraw}-\mathrm{Hill}, 1951)$. The author is indebted
the Bureau for the application of this test to these data. 
TABLE 5. Visual alinement of solutions of white sugars arranged in order of decreasing color

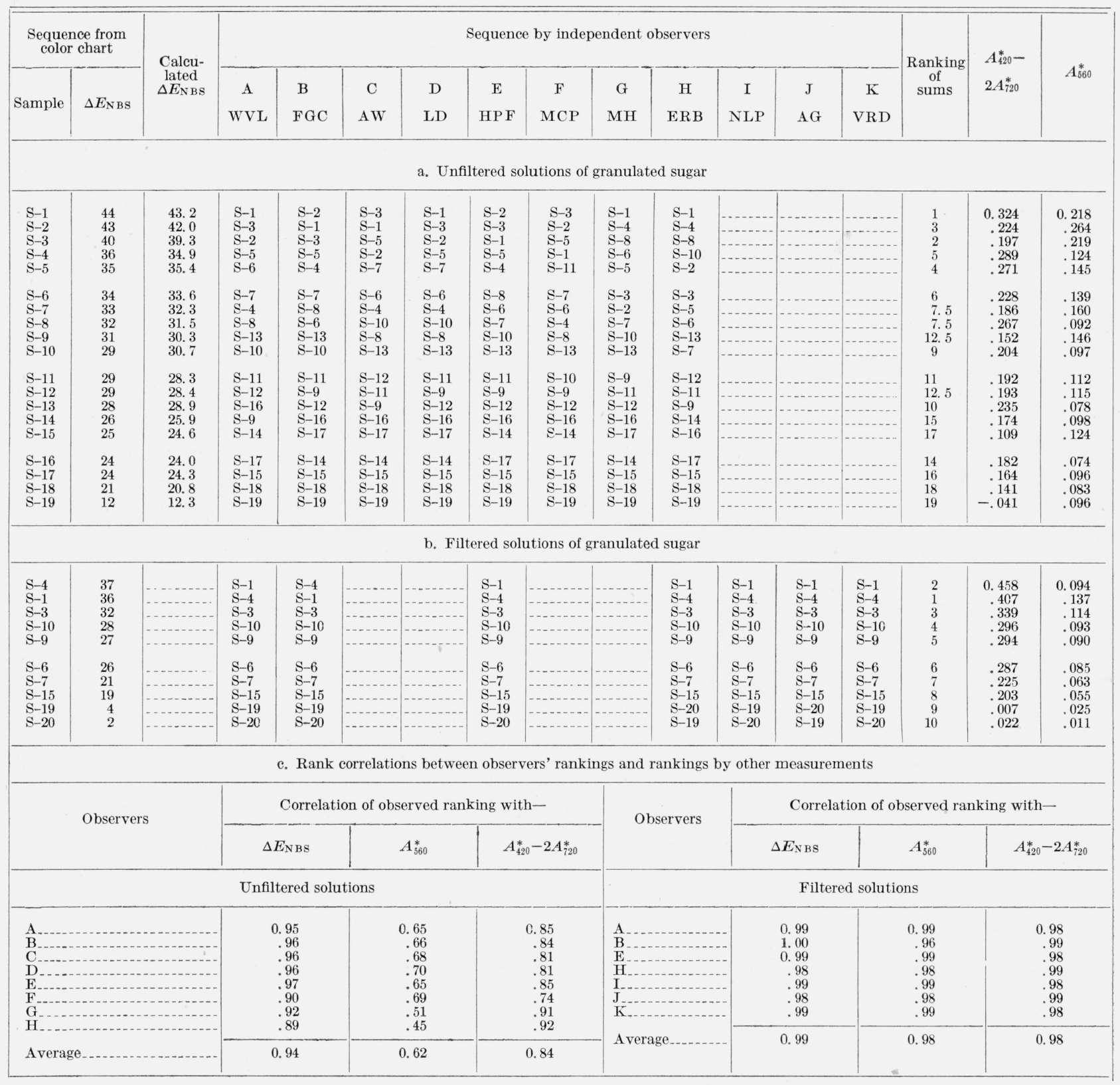

filled to a depth of $15 \mathrm{~cm}$. In one case the tubes were painted black on the outside, with the exception of the curved bottom surface, and in the other case the tubes were unpainted. The solutions were viewed with a light source and a surrounding field consisting of thin white paper placed over a fluorescent tube (15-w daylight).

The results are given in table 6 , which also includes the values corresponding to $\Delta E_{\mathrm{NBS}}, \mathrm{A}_{560}^{*}$, and the quantity $A_{420}^{*}-2 A_{720}^{*}$. The coefficient of concordance among the 10 observers was 0.92 for the measurements with clear test tubes and 0.90 in the blackened tubes.
The rank correlations between each of the 10 individual observers' rankings and each of the rankings according to $\Delta E_{\mathrm{NBS}}, A_{560}^{*}$, and $A_{420}^{*}-2 A_{720}^{*}$ were calculated. The results are shown in table 7 . There appears to be a significant tendency for observers' rankings for clear tubes to agree better with the ranking according to $A_{560}^{*}$ than with the ranking according to $\Delta E_{\mathrm{NBs}}$. It is to be noted, however, that the differences between an observer's rank correlation coefficients for $\Delta E_{\mathrm{NBS}}$ and $A_{560}^{*}$ are very small. For blackened test tubes, there is no significant difference between $\Delta E_{\mathrm{NBS}}$ and $A_{560}^{*}$ with respect to their agreement with observers' rankings. 
TABLE 6.-Visual alinement of solutions of white sugars observed in painted and unpainted test tubes

\begin{tabular}{|c|c|c|c|c|c|c|c|c|c|c|c|c|c|c|c|c|}
\hline \multirow[b]{2}{*}{ Sample } & \multirow[b]{2}{*}{$\Delta E_{\mathrm{NBS}}{ }^{a}$} & \multicolumn{11}{|c|}{ Sequence of diminishing color by independent observers } & \multicolumn{4}{|c|}{$\begin{array}{l}\text { Data with Beckman DU } \\
\text { spectrophotometer }\end{array}$} \\
\hline & & $\begin{array}{c}\text { LPD } \\
\text { I }\end{array}$ & $\begin{array}{c}\text { HPF } \\
\text { II }\end{array}$ & $\begin{array}{c}\text { WVL } \\
\text { III }\end{array}$ & $\begin{array}{c}\text { FGC } \\
\text { IV }\end{array}$ & $\begin{array}{l}\mathrm{AG} \\
\mathrm{V}\end{array}$ & $\begin{array}{c}\text { VRD } \\
\text { VI }\end{array}$ & $\begin{array}{l}\text { MP } \\
\text { VII }\end{array}$ & $\begin{array}{l}\text { ERB } \\
\text { VIII }\end{array}$ & $\begin{array}{c}\text { НКН } \\
\text { IX }\end{array}$ & $\begin{array}{c}\text { IN } \\
\mathrm{X}\end{array}$ & Ranking & $\begin{array}{c}\text { Cell } \\
\text { depth }\end{array}$ & $\begin{array}{l}\text { Solids } \\
\text { concen- } \\
\text { tration }\end{array}$ & $A_{560}^{*}$ & $\begin{array}{l}A_{420}^{*}- \\
2 A_{720}^{*}\end{array}$ \\
\hline \multicolumn{17}{|c|}{ Unpainted test tubes } \\
\hline $\begin{array}{l}5 \\
2 \\
2 \\
1 \\
4 \\
8 \\
8 \\
7 \\
3 \\
6 \\
9 \\
9\end{array}$ & $\begin{array}{l}48.1 \\
47.9 \\
47.0 \\
32.9 \\
31.2 \\
\\
30.3 \\
29.1 \\
28.0 \\
27.2\end{array}$ & $\begin{array}{l}5 \\
2 \\
1 \\
8 \\
4\end{array}$ & $\begin{array}{l}5 \\
2 \\
1 \\
8 \\
4 \\
6 \\
6 \\
7 \\
9 \\
3\end{array}$ & $\begin{array}{l}2 \\
5 \\
1 \\
8 \\
7 \\
4 \\
4 \\
9 \\
3 \\
6\end{array}$ & $\begin{array}{l}2 \\
5 \\
1 \\
4 \\
8 \\
\\
7 \\
6 \\
3 \\
9\end{array}$ & $\begin{array}{l}5 \\
2 \\
1 \\
8 \\
4 \\
7 \\
9 \\
6 \\
3\end{array}$ & $\begin{array}{l}2 \\
1 \\
5 \\
8 \\
4 \\
7 \\
7 \\
6 \\
3 \\
9\end{array}$ & $\begin{array}{l}1 \\
2 \\
5 \\
8 \\
4 \\
9 \\
9 \\
6 \\
3 \\
7\end{array}$ & $\begin{array}{l}2 \\
5 \\
1 \\
8 \\
7 \\
4 \\
4 \\
9 \\
6 \\
3\end{array}$ & $\begin{array}{l}5 \\
2 \\
1 \\
8 \\
4\end{array}$ & $\begin{array}{l}2 \\
1 \\
5 \\
8 \\
7\end{array}$ & $\begin{array}{l}2 \\
1 \\
3 \\
5 \\
4 \\
\\
6 \\
9 \\
7.5 \\
7.5\end{array}$ & $\begin{array}{c}c m \\
10 \\
10 \\
10 \\
10 \\
10 \\
10 \\
10 \\
10 \\
10\end{array}$ & $\begin{array}{r}{ }^{\circ} \text { Brix } \\
49.3 \\
50.0 \\
49.9 \\
50.1 \\
50.1 \\
\\
49.3 \\
50.1 \\
49.7 \\
50.1\end{array}$ & $\begin{array}{r}0.085 \\
.080 \\
.080 \\
.049 \\
.048 \\
\\
.043 \\
.037 \\
.038 \\
.034\end{array}$ & $\begin{array}{r}0.234 \\
.236 \\
.224 \\
.161 \\
.146 \\
.136 \\
.142 \\
.129 \\
.133\end{array}$ \\
\hline \multicolumn{17}{|c|}{ Sides of test tubes painted black } \\
\hline $\begin{array}{l}5 \ldots \\
2 \\
1 \\
4 \\
8\end{array}$ & $\begin{array}{l}48.1 \\
47.9 \\
47.0 \\
32.9 \\
31.2\end{array}$ & $\begin{array}{l}5 \\
2 \\
1 \\
8 \\
7\end{array}$ & $\begin{array}{l}5 \\
2 \\
1 \\
8 \\
7\end{array}$ & $\begin{array}{l}2 \\
5 \\
1 \\
8 \\
4\end{array}$ & $\begin{array}{l}5 \\
2 \\
1 \\
7 \\
8\end{array}$ & $\begin{array}{l}5 \\
2 \\
1 \\
8 \\
7\end{array}$ & $\begin{array}{l}5 \\
2 \\
1 \\
8 \\
7\end{array}$ & $\begin{array}{l}5 \\
1 \\
8 \\
2 \\
7\end{array}$ & $\begin{array}{l}1 \\
2 \\
5 \\
4 \\
8\end{array}$ & $\begin{array}{l}1 \\
2 \\
5 \\
8 \\
7\end{array}$ & $\begin{array}{l}2 \\
1 \\
5 \\
8 \\
4\end{array}$ & $\begin{array}{l}1 \\
2 \\
3 \\
6 \\
4\end{array}$ & & & & \\
\hline $\begin{array}{l}7 \ldots \\
3- \\
6 \\
9\end{array}$ & $\begin{array}{l}30.3 \\
29.1 \\
28.0 \\
27.2\end{array}$ & $\begin{array}{l}4 \\
3 \\
9 \\
6\end{array}$ & $\begin{array}{l}4 \\
6 \\
9 \\
3\end{array}$ & $\begin{array}{l}7 \\
3 \\
6 \\
9\end{array}$ & $\begin{array}{l}3 \\
4 \\
9 \\
6\end{array}$ & $\begin{array}{l}4 \\
6 \\
9 \\
3\end{array}$ & $\begin{array}{l}4 \\
6 \\
9 \\
3\end{array}$ & $\begin{array}{l}4 \\
9 \\
6 \\
3\end{array}$ & $\begin{array}{l}3 \\
7 \\
6 \\
9\end{array}$ & $\begin{array}{l}4 \\
9 \\
3 \\
6\end{array}$ & $\begin{array}{l}7 \\
6 \\
9 \\
3\end{array}$ & $\begin{array}{l}5 \\
7.5 \\
7.5 \\
9\end{array}$ & & & & \\
\hline
\end{tabular}

a Corresponding to a cell depth of $15 \mathrm{~cm}$ and a sugar-solids concentration of $1 \mathrm{~g} / \mathrm{ml}$.

TABLE 7. Rank correlations between observers' rankings and rankings by other measurements

\begin{tabular}{|c|c|c|c|}
\hline \multirow{2}{*}{ Observers } & \multicolumn{3}{|c|}{ Correlation of observed ranking with- } \\
\hline & $\Delta E_{\mathrm{NBS}}$ & $A_{560}^{*}$ & $A_{420}^{*}-2 A_{720}^{*}$ \\
\hline \multicolumn{4}{|c|}{ Clear tubes } \\
\hline $\begin{array}{l}\text { I } \\
\text { II } \\
\text { III } \\
\text { IV } \\
\text { V } \\
\text { VI } \\
\text { VII } \\
\text { VIII } \\
\text { IX } \\
\text { X }\end{array}$ & $\begin{array}{l}0.92 \\
.90 \\
.88 \\
.97 \\
.92 \\
.92 \\
.75 \\
.87 \\
.93 \\
.83\end{array}$ & $\begin{array}{l}0.93 \\
.95 \\
.85 \\
.97 \\
.93 \\
.92 \\
.78 \\
.87 \\
.96 \\
.85\end{array}$ & $\begin{array}{l}0.87 \\
.82 \\
.88 \\
.92 \\
.87 \\
.88 \\
.80 \\
.83 \\
.85 \\
.82\end{array}$ \\
\hline A verage .... & 0.89 & 0.90 & 0.85 \\
\hline \multicolumn{4}{|c|}{ Blackened tubes } \\
\hline $\begin{array}{l}\text { I } \\
\text { II } \\
\text { III } \\
\text { IV } \\
\text { V } \\
\text { VI } \\
\text { VII } \\
\text { VIII } \\
\text { IX } \\
\mathrm{X}\end{array}$ & $\begin{array}{l}0.93 \\
.90 \\
.97 \\
.87 \\
.90 \\
.90 \\
.82 \\
.92 \\
.83 \\
.88\end{array}$ & $\begin{array}{r}0.90 \\
.93 \\
.94 \\
.81 \\
.93 \\
.93 \\
.85 \\
.90 \\
.83 \\
.91\end{array}$ & $\begin{array}{l}0.90 \\
.80 \\
.95 \\
.83 \\
.80 \\
.80 \\
.72 \\
.93 \\
.83 \\
.85\end{array}$ \\
\hline A verage ...... & 0.89 & 0.89 & 0.84 \\
\hline
\end{tabular}

The significant tendency for $\Delta E_{\mathrm{NBS}}$ to agree with observed rankings better than $A_{420}^{*}-2 A_{720}^{*}$ is maintained in this experiment.

It is obvious that the values for $\Delta E_{\mathrm{NBS}}$ are as successful as other available measurements in alining the solutions of sugars in order of decreasing color.
Furthermore, there is a marked tendency for alinement according to $\Delta E_{\mathrm{NBS}}$ to agree better with observed rankings than either of $A_{560}^{*}$ or $A_{420}^{*}-2 A_{720}^{*}$ when the evaluation of color is complicated by the presence of turbidity.

It may be concluded, therefore, that values of $\Delta E_{\mathrm{NBS}}$ can be used with confidence by the sugar industry in grading the color of normal sugar liquors. Additional comparisons are, of course, very much to be desired for the possible recognition of some new aspect of the sugar colorant not as yet encountered.

\subsection{Approximation of the Spectrophotometric Data by Two Straight Lines}

For some sugars the relation between log attenuancy and log wavelength (fig. 3) is sufficiently nonlinear, as shown in figure 6 , to cause errors of as much as 8 color units when the color chart is used in the determination of $\Delta E_{\mathrm{NBS}}$. Values of $\Delta E_{\mathrm{NBS}}$ calculated from the transmittancy data are given in table 8 for a typical group of sugars. The $\Delta E_{\mathrm{NBS}}$ values obtained from the color chart are entered under the column headed " $\Delta E_{1}$."

It has been found possible, for the practical purpose of a rapid color evaluation, to represent the dependence on wavelength in these cases by two straight lines (fig. 6), one for the blue portion of the visible spectrum and one for the remainder of the spectrum. The values for the slopes of four sugars are given in table 8 , and the "blue line" has a steeper slope than the "yellow line." An empirical rule whereby the correct $\Delta E_{\mathrm{NBS}}$ may be obtained from the color chart is as follows: (1) Calculate a weighted 
TABLE 8. Calculation of $\Delta E_{\mathrm{NBS}}$ values for several filtered solutions of raw sugars (no adjustment for $p \mathrm{H}$ was made in these cases)

\begin{tabular}{|c|c|c|c|c|c|c|c|}
\hline \multirow{2}{*}{ Solution } & \multirow{2}{*}{$\begin{array}{c}\text { Cell } \\
\text { depth }\end{array}$} & \multirow{2}{*}{$\begin{array}{l}\text { Sugar } \\
\text { solids }\end{array}$} & \multicolumn{2}{|c|}{ Slope of line } & \multirow{2}{*}{$\begin{array}{c}\quad \Delta E_{1} \\
\text { (assuming } \\
\text { linearity) }\end{array}$} & \multirow{2}{*}{$\begin{array}{l}\Delta E_{\mathrm{NBS}} \\
\text { (2/3 rule) }\end{array}$} & \multirow{2}{*}{$\begin{array}{c}\Delta E_{\mathrm{NBS}} \\
\text { calculated } \\
\text { by eq (1) }\end{array}$} \\
\hline & & & Yellow & Blue & & & \\
\hline $\begin{array}{l}\text { Australian raw, No. } 1(p \mathrm{H}=5.7) \\
\text { Australian raw, No. } 2(p \mathrm{H}=5.9) \\
\text { Australian raw, No. } 3(p \mathrm{H}=5.9) \\
\text { Hawaiian raw, No. } 17(p \mathrm{H}=5.7)\end{array}$ & $\begin{array}{l}c m \\
1.0 \\
1.0 \\
1.0 \\
0.2\end{array}$ & $\begin{array}{l}{ }^{\circ} \mathrm{Brix} \\
58.3 \\
60.3 \\
61.8 \\
60.3\end{array}$ & $\begin{array}{l}3.8 \\
3.7 \\
3.8 \\
4.9\end{array}$ & $\begin{array}{l}7.8 \\
6.3 \\
6.3 \\
6.8\end{array}$ & $\begin{array}{l}61 \\
53 \\
46 \\
34\end{array}$ & $\begin{array}{l}57 \\
48 \\
43 \\
33\end{array}$ & $\begin{array}{l}56.8 \\
48.0 \\
41.8 \\
32.7\end{array}$ \\
\hline
\end{tabular}

average for the attenuation at $420 \mathrm{~m} \mu$ by taking two-thirds of the observed reading and one-third of the value when the "yellow line" is extrapolated to $420 \mathrm{~m} \mu$. (2) Combine this average with the observed attenuation at $560 \mathrm{~m} \mu$ and read the corresponding $\Delta E_{\mathrm{NBS}}$ from the color chart. Nothing additional is gained by using more than two straight lines to present the data.

The $\Delta E_{\mathrm{NBS}}$ values for the raw sugars listed in table 8 were calculated by the above empirical rule. The agreement with the correct values is satisfactory. No particular physical significance is attributed to the use of the two straight lines nor to the factor two-thirds.

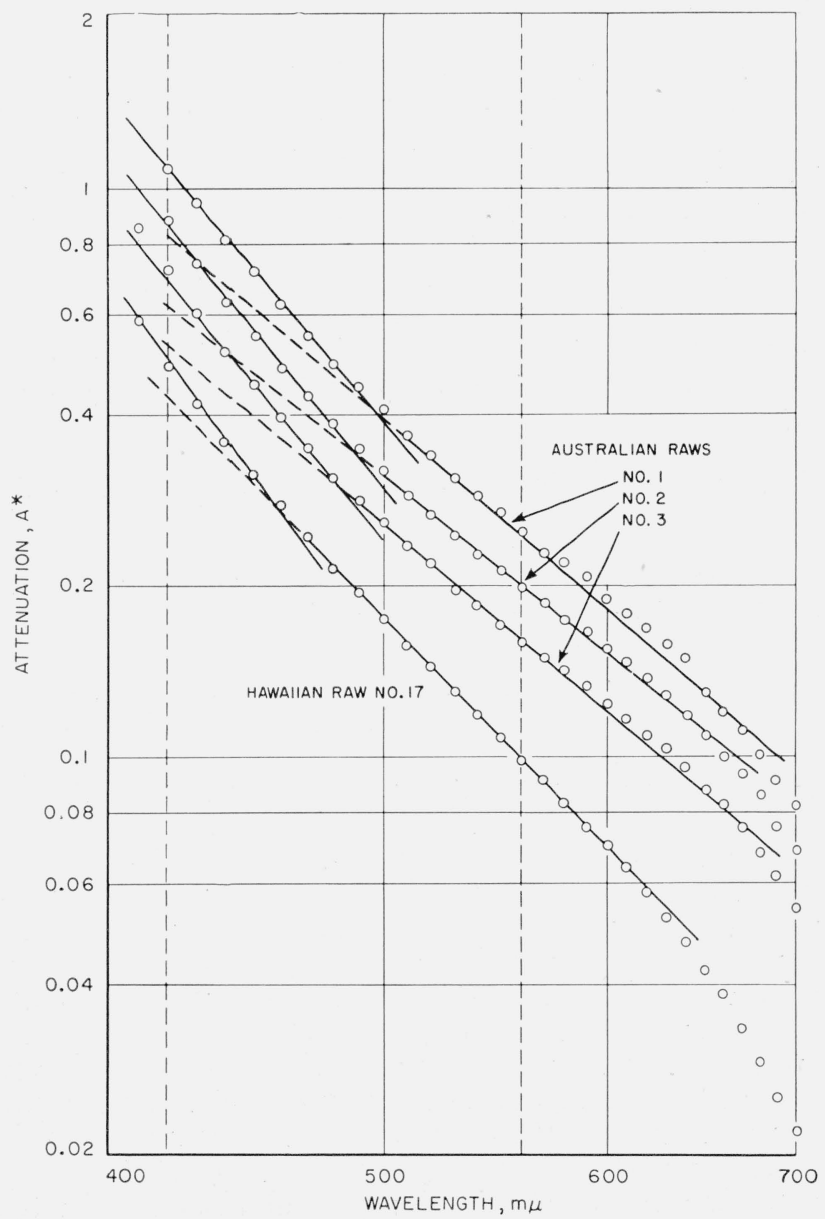

Figure 6. Attenuancy plotted versus wavelength on log-log scales for sugars listed in table 8.
The increase in slope of the absorption curves on going from the red to the blue portion of the visible spectrum continues in the near ultraviolet. Two examples are given in figure 7 , one for a washed Cuban raw sugar $\left(60^{\circ}\right.$ Brix and $1-\mathrm{cm}$ depth) and the other for a granulated sugar solution $\left(60^{\circ}\right.$ Brix and $10-$ $\mathrm{cm}$ depth). If the straight line observed in the visible region ( 470 to $620 \mathrm{~m} \mu$ ) in the $\log -\log$ plot (fig. 3) were extended into the ultraviolet, it would correspond in the nonlogarithmic plot to the curvature given by the dotted lines in figure 7 . There is no a priori reason for the tail of the absorption curve of a sugar to fall off logarithmically. Consequently, it may be expected that the simple behavior illustrated in figure 3 does not hold in all cases. In fact, it is remarkable that it is valid as frequently as is observed.

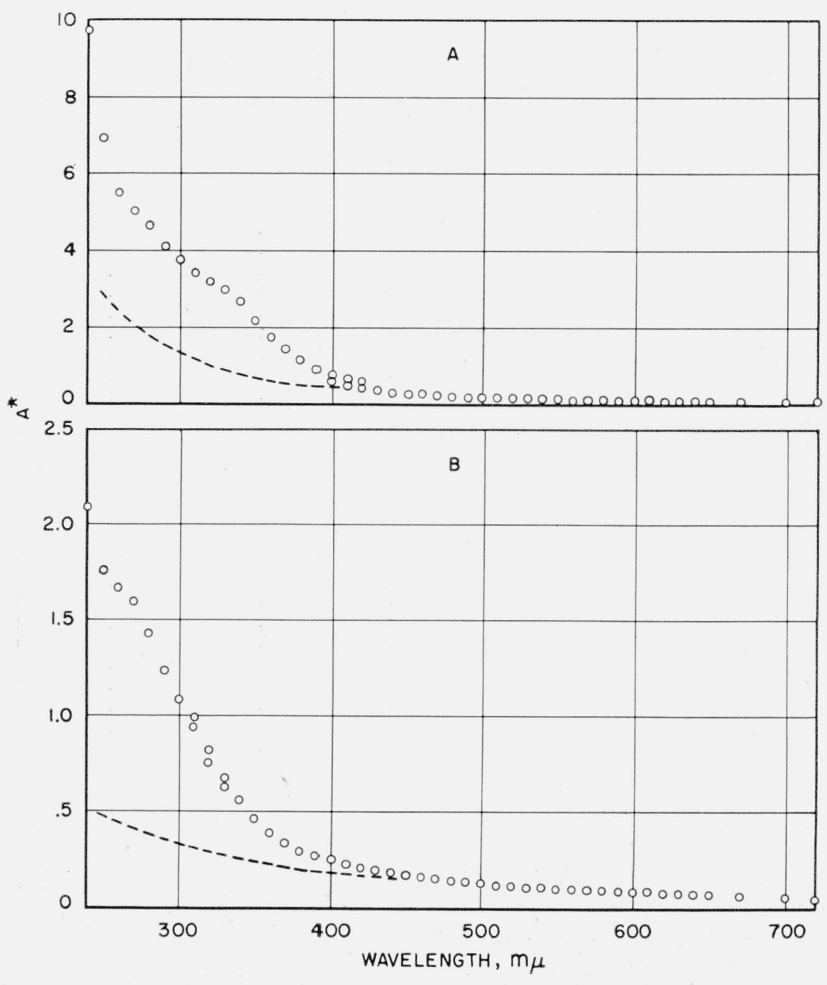

FIgURE 7. Attenuation plotted as a function of wavelength (linear scales).

A, Washed Cuban raw $\left(60^{\circ}\right.$ Brix and 1-cm depth); B, granulated sugar $\left(60^{\circ}\right.$ Brix and 10-cm depth) 


\section{Visual Color of Mixtures of Sugar Liquors}

It is often desirable to predict the color of a mixture from that of its component liquors. A method to accomplish this is presented below. All mixtures and components will be considered to be at the same $p \mathrm{H}$ and at the same concentration of total sugar solids. The problem is to express the visual color in $\Delta E_{\mathrm{NBS}}$ units as a function of the relative volumes of the known component liquors. The two components of a sugar liquor may, of course, differ so widely in visual color that different cell depths are necessary to obtain the necessary attenuation data. For example, it may be desired to mix small quantities of a dark liquor with a light-colored liquor. Because the $\Delta E_{\mathrm{NBS}}$ value is almost directly proportional to the cell depth, for $\Delta E_{\mathrm{NBS}}$ values less than 40 , the correction to constant cell depth can readily be made.

The color of a binary mixture contained in a cell depth of $b_{\text {mix }}$ was found to satisfy eq (2)

$\Delta E_{\text {mix }}=\left[\frac{V_{1}}{\left(V_{1}+V_{2}\right)} \Delta E_{1} \frac{b_{\text {mix }}}{b_{1}}\right]+\left[\frac{V_{2}}{\left(V_{1}+V_{2}\right)} \Delta E_{2} \frac{b_{\text {mix }}}{b_{2}}\right]$,

where

$r_{1}, V_{2}=$ volumes of components 1 and 2 in the mixture, respectively.

$\Delta E_{1}, \Delta E_{2}=$ visual color of components 1 and 2 , respectively.

$b_{1}, b_{2}=$ depths at which $\Delta E_{1}$ and $\Delta E_{2}$ were determined, respectively.

In order to test this relationship, a number of binary mixtures of sugar liquors were examined. The sugar solutions were obtained from a Hawaiian raw sugar (No. 17), a washed Cuban raw sugar (No. 15), and from two granulated sugars (D. P. T. and No. 29). The two raw sugars were dissolved and filtered by using a diatomaceous filter aid, and the solutions of the granulated sugars were filtered through a "medium" sintered-glass filter. The $p \mathrm{H}$ of each of the sugar liquors was carefully adjusted to 7. A comparison of calculated and observed values of $\Delta E_{\mathrm{mix}}$ is shown in table 9 for four series of mixtures. The observed value for $\Delta E_{\mathrm{mix}}$ was obtained from the observed and extrapolated values of $A_{420}^{*}$ in the manner described in section 4.3. The calculated value was obtained from eq (2). The validity of the formula is indicated by the good agreement.

One important conclusion can be drawn from the above agreement, namely, that $\Delta E_{\mathrm{NBS}}$ is proportional to the cell depth when $\Delta E_{\mathrm{NBS}}$ is less than 40 . For routine evaluation, it is only necessary to determine the $\Delta E_{\mathrm{NBS}}$ value of a reference liquor from the attenuation data and compare other unknown liquors to this by a determination of equivalent cell depth. It is possible to calculate $\Delta E_{\mathrm{mix}}$, even though the individual components were contained at different cell depths. The following measurements illustrate this point. A solution of a washed Cuban raw sugar was used with a solution of granulated sugar. A 5-cm
TABLE 9. Color in binary mixtures of sugar liquors

\begin{tabular}{|c|c|c|c|c|c|c|}
\hline \multicolumn{2}{|c|}{ Sugar liquor } & \multicolumn{2}{|c|}{ Observed values } & \multirow{2}{*}{$\begin{array}{c}\begin{array}{c}\text { Extrap- } \\
\text { olated } \\
\text { value }\end{array} \\
A_{420}^{*}\end{array}$} & \multicolumn{2}{|c|}{$\Delta E_{\mathrm{mix}}$} \\
\hline A & B & $A_{420}^{*}$ & $A_{560}^{*}$ & & $\begin{array}{l}\text { Ob- } \\
\text { served } a\end{array}$ & $\begin{array}{l}\text { Calcu- } \\
\text { lated by } \\
\text { eq (2) }\end{array}$ \\
\hline \multicolumn{7}{|c|}{$\begin{array}{c}\text { Series 1: Solution A contained washed Cuban raw sugar No, } 15 \text {, and B } \\
\text { Hawaiian raw sugar N } 17 \text { (cell deptb } 0.2 \mathrm{~cm}, 60^{\circ} \text { Brix). }\end{array}$} \\
\hline $\begin{array}{r}\% \\
0 \\
25 \\
50 \\
75 \\
100\end{array}$ & $\begin{array}{r}\% \\
100 \\
75 \\
50 \\
25 \\
0\end{array}$ & $\begin{array}{r}0.665 \\
.524 \\
.383 \\
.235 \\
.096\end{array}$ & $\begin{array}{r}0.114 \\
.088 \\
.062 \\
.036 \\
.012\end{array}$ & $\begin{array}{r}0.505 \\
.401 \\
.278 \\
.182 \\
.071\end{array}$ & $\begin{array}{r}42 \\
35 \\
26 \\
17 \\
6\end{array}$ & $\begin{array}{l}33 \\
24 \\
16 \\
\end{array}$ \\
\hline
\end{tabular}

Series 2: Solution A contained granulated sugar No. 29 and B granulated sugar D. P. T. (cell depth $10 \mathrm{~cm}, 50^{\circ}$ Brix).

\begin{tabular}{r|r|r|r|r|r|r}
\hline 0 & 100 & 0.305 & 0.063 & 0.305 & 23 & \\
25 & 75 & .276 & .065 & .276 & 21 & 22 \\
50 & 50 & .247 & .070 & .247 & 19 & 20 \\
75 & 25 & .218 & .073 & .218 & 16 & 17 \\
100 & 0 & .190 & .079 & .190 & 14 & $\cdots$ \\
\hline
\end{tabular}

Series 3: Solution A contained granulated sugar No. 29 and B washed Cuban raw sugar No. 15 (cell depth $1 \mathrm{~cm}, 60^{\circ}$ Brix).

\begin{tabular}{r|r|r|r|r|r|r}
\hline 0 & 100 & 0.459 & 0.078 & 0.275 & 29 & \\
3 & 97 & .446 & .075 & .260 & 28 & 28 \\
6 & 94 & .435 & .073 & .250 & 28 & 27 \\
10 & 90 & .416 & .067 & .237 & 27 & 26 \\
15 & 85 & .398 & .065 & .227 & 26 & 25 \\
20 & 80 & .341 & .067 & .236 & 23 & 24 \\
100 & 0 & .019 & .008 & .017 & 2 & $\cdots$ \\
\hline
\end{tabular}

Series 4: Solution A contained Hawaiian raw sugar No. 17 and B washed Cuban raw sugar No. 15 (cell depth $0.2 \mathrm{~cm}, 60.5^{\circ} \mathrm{Brix}$ ).

\begin{tabular}{r|r|r|r|r|r|r|}
\hline 100 & 0 & 0.775 & 0.120 & 0.550 & 47 & \\
95 & 5 & .744 & .118 & .522 & 45 & 45 \\
90 & 10 & .715 & .111 & .495 & 44 & 43 \\
50 & 50 & .451 & .066 & .321 & 30 & 28 \\
20 & 80 & .250 & .034 & .167 & 17 & 16 \\
5 & 95 & .150 & .018 & .101 & 11 & 11 \\
0 & 100 & .118 & .014 & .076 & 9 & $\cdots$ \\
\hline
\end{tabular}

a Determined from observed attenuancies for the binary mixtures and the color chart of figure 5 .

cell and a 1-cm cell were mounted in series in the 10-cm cell compartment of the Beckman DU Spectrophotometer on both the solution and the reference side. Prisms were inserted in the $1-\mathrm{cm}$ cell in order to form either a $0.2-$ or $0.5-\mathrm{cm}$ depth of liquor. In these measurements the cell depth $\left(b_{\mathrm{mix}}\right)$ is not the same for both terms of eq (2), which must now be written

$\Delta E_{\text {mix }}=\left[\frac{V_{1}}{\left(V_{1}+V_{2}\right)} \Delta E_{1} \frac{b_{\text {mix }}^{\prime}}{b_{1}}\right]+\left[\frac{V_{2}}{\left(V_{1}+V_{2}\right)} \Delta E_{2} \frac{b_{\text {mix }}^{\prime \prime}}{b_{2}}\right]$.

The cell depth associated with $\Delta E_{\mathrm{mix}}$ is the equivalent depth of any component in the mixture in terms of the reference component measured at $b_{1}\left(\right.$ or $\left.b_{2}\right)$. The factors $b_{\text {mix }}^{\prime}$ and $b_{\text {mix }}^{\prime \prime}$ denote that they refer to the separate components.

The results are summarized in table 10 . There is quite satisfactory agreement between experiment and the calculated value, using eq (3).

An examination of the color chart (fig. 5) shows that for a given ratio of $A_{420}^{*}$ to $A_{560}^{*}, \Delta E_{\mathrm{NBS}}$ is nearly proportional to $A_{420}^{*}$ for values less than 40 . If the ratios of $A_{420}^{*}$ to $A_{560}^{*}$ fall within the range from 6 to 2 , it can be shown from the color chart that $\Delta E_{\mathrm{NBS}}$ is 


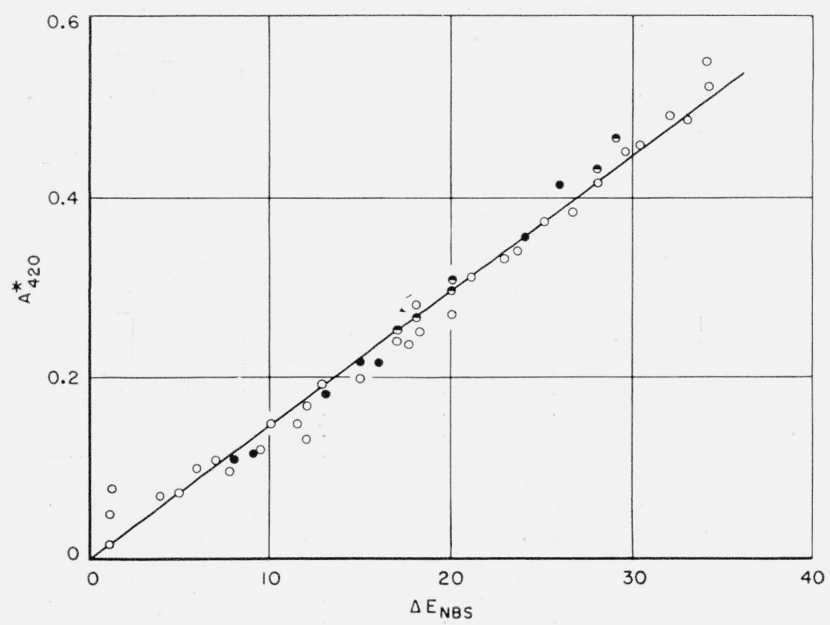

Figure 8. A plot of attenuation at 420 millimicrons (ordinate) as a function of $\Delta E_{\mathrm{NBS}}$ for a variety of sugar liquors.

○, 10-cm cell depth, $60^{\circ}$ Brix; $\bullet, 5.5$-cm cell depth, $60^{\circ}$ Brix; $\bigcirc, 1.0$-cm cell depth, $60^{\circ}$ Brix.

proportional to $A_{420}^{*}$ within about \pm 2 units for $\Delta E_{\mathrm{NBS}}$ less than 40 . The degree of approximation this involves may be seen in figure 8 , in which the observed attenuation at $420 \mathrm{~m} \mu$ is plotted as a function of $\Delta E_{\mathrm{NBS}}$ for a large variety of sugar liquors. A linear relationship is observed within an average deviation of about $4 \Delta E_{\mathrm{NBS}}$ units. This fact may find practical applications except in those solutions with very low values of $\Delta E_{\mathrm{NBS}}$ where the degree of turbidity is sufficient to modify the transmittancy.

\section{TABLE 10. Additivity of sugar color in NBS units}

Solution A contained granulated sugar No. 29 and solution B contained washed Cuban raw sugar No. 15.

\begin{tabular}{|c|c|c|c|c|c|}
\hline \multicolumn{4}{|c|}{$\begin{array}{l}\text { Composition of sugar mixture at designated cell depth } \\
\text { (combined in series) }\end{array}$} & \multicolumn{2}{|c|}{$\Delta E_{\mathrm{NBS}}$ value } \\
\hline $5.0 \mathrm{~cm}$ & $1.0 \mathrm{~cm}$ & $0.5 \mathrm{~cm}$ & $0.2 \mathrm{~cm}$ & $\begin{array}{c}\text { Ob- } \\
\text { served } a\end{array}$ & $\begin{array}{l}\text { Calcu- } \\
\text { lated } \\
\text { from } \\
\text { eq (5) }\end{array}$ \\
\hline $100 \% \mathrm{~A} \ldots \ldots$ & $100 \% \mathrm{~B}$ & & $100 \%$ A & $\begin{array}{r}9 \\
36\end{array}$ & \\
\hline $\begin{array}{l}100 \% \mathrm{~A} \\
96 \% \mathrm{~A}+4 \% \mathrm{~B}^{-}\end{array}$ & & & $100 \% \mathrm{~B}$ & $\begin{array}{l}16 \\
15\end{array}$ & $\begin{array}{l}16 \\
16\end{array}$ \\
\hline $100 \% \mathrm{~A}$ & & $100 \% \mathrm{~B}$ & & 24 & 27 \\
\hline $91 \% \mathrm{~A}+9 \% \mathrm{~B}$ & & $91 \% \mathrm{~A}+9 \% \mathrm{~B}$ & & 27 & 26 \\
\hline
\end{tabular}

a Determined from observed attenuancies for the sugar mixtures and the color chart of figure 5 .

\section{Discussion}

A fundamental scale of sugar color, called the NBS scale, is presented and has been used to express the color value of a variety of commercial sugar products. The results are in good agreement with visual estimations of color. It is proposed that all sugar colors be evaluated by the difference between their color and that of a colorless sucrose solution, instead of by luminous transmittance and chromaticity coordinates $x, y$. Some information is lost by omitting the complete color specifications, but this is balanced, at least in part, by the gain in simplicity.

The spectrophotometric data for commercial sugar solutions has a relatively simple character and can be represented by a simple algebraic relationship in the visible spectrum. A color chart is presented from which the $\Delta E_{\mathrm{NBS}}$ value of a color can be read directly from a knowledge of the attenuation at 420 and $560 \mathrm{~m} \mu$.

It has been shown that color on this scale is an additive property and, therefore, it can be used to express percentage changes in the removal of visual color effected by various refining steps. There is a good possibility that the useful limit on the magnitude of the color value can be increased beyond 40 . In this case, the scale would then serve as a suitable means to measure the color of very dark products.

It must be noted that $\Delta E_{\mathrm{NBS}}$ was calculated from the transmitted light only. Therefore, caution must be used in visual comparisons to take into account the light reflected from container walls. The NBS unit fulfills the need for a primary color standard in the sugar industry, although secondary standards, such as suitable glasses, will also be found useful.

\section{References}

[1] R. S. McCulloh, Senate Document 209, vol. 3, 2d session of the 29th Congress (1846-47).

[2] M. Payen, Mémoire sur le charbon animal, J. pharm. accessoires 8, 278-93 (1822).

[3] F. W. Zerban, The color problem in sucrose manufacture, Technol. Rept. Ser. 2, Sugar Research Foundation (Aug. 1947).

[4] T. R. Gillett, Color and colored nonsugars, p. 214-90, Principles of sugar technology, edited by Pieter Honig (Elsevier Publishing Co., New York, N. Y., 1953).

[5] F. W. Zerban, L. Sattler, and J. Martin, Spectrophotometric studies on refined sugars in solution, Anal. Chem. 23, 308-13 (1951).

[6] F. W. Zerban, J. Martin, and C. Erb, Spectrophotometric studies on raw cane sugars in solution, Anal. Chem. 24, $168-70$ (1952).

[7] R. W. Liggett and Victor R. Deitz, Color and turbidity of sugar products, Advances in Carbohydrate Chem. 9, figure 9, p. 266 (1954).

[8] D. B. Judd, Colorimetry, NBS Circ. 478 (1950).

[9] D. B. Judd, Color in business, science, and industry (John Wiley \& Sons, Inc., New York, N. Y., 1952).

[10] D. Nickerson, Tables for use in computing small color differences, Am. Dyestuff Reptr. 39, 541 (1950).

[11] T. R. Gillett and W. D. Heath, Recent developments in white sugar colorimetry, Anal. Chem. 26, 1780-84 (1954).

[12] V. R. Deitz, N. L. Pennington, and H. L. Hoffman, Jr., Transmittancy of commercial sugar liquors: dependence on concentration of total solids, J. Research NBS 49, 365-69 (1952) RP2373.

[13] H. H. Peters and F. P. Phelps, A technical method of using the mercury arc to obtain data at wave length $560 \mathrm{~m} \mu$ in the spectrophotometric analysis of sugar products, BS J. Research 2, 335-42 (1928) RP38.

Washington, March 30, 1956. 